\title{
Genome-wide analysis of 5-hmC in the peripheral blood of systemic lupus erythematosus patients using an hMeDIP-chip
}

\author{
WEIGUO SUI $^{1 *}$, QIUPEI TAN $^{1 *}$, MING YANG $^{1}$, QIANG YAN $^{1}$, HUA LIN $^{1}$, MINGLIN OU $^{1}$, \\ WEN XUE ${ }^{1}$, JIEJING CHEN ${ }^{1}$, TONGXIANG ZOU ${ }^{1}$, HUANYUN JING ${ }^{1}$, LI GUO $^{1}$, \\ CUIHUI CAO ${ }^{1}$, YUFENG SUN ${ }^{1}$, ZHENZHEN CUI ${ }^{1}$ and YONG DAI ${ }^{2}$ \\ ${ }^{1}$ Guangxi Key Laboratory of Metabolic Diseases Research, Central Laboratory of Guilin 181st Hospital, \\ Guilin, Guangxi 541002; ${ }^{2}$ Clinical Medical Research Center, the Second Clinical Medical College \\ of Jinan University (Shenzhen People's Hospital), Shenzhen, Guangdong 518020, P.R. China
}

Received July 9, 2014; Accepted February 27, 2015

DOI: $10.3892 / \mathrm{ijmm} .2015 .2149$

\begin{abstract}
Systemic lupus erythematosus (SLE) is a chronic, potentially fatal systemic autoimmune disease characterized by the production of autoantibodies against a wide range of self-antigens. To investigate the role of the 5-hmC DNA modification with regard to the onset of SLE, we compared the levels 5-hmC between SLE patients and normal controls. Whole blood was obtained from patients, and genomic DNA was extracted. Using the hMeDIP-chip analysis and validation by quantitative RT-PCR (RT-qPCR), we identified the differentially hydroxymethylated regions that are associated with SLE. There were 1,701 genes with significantly different 5-hmC levels at the promoter region in the SLE patients compared with the normal controls. The $\mathrm{CpG}$ islands of 3,826 genes showed significantly different 5-hmC levels in the SLE patients compared with the normal controls. Out of the differentially hydroxymethylated genes, three were selected for validation, including TREXI,CDKN1A and $C D K N 1 B$. The hydroxymethylation levels of the three genes were confirmed by RT-qPCR. The results suggested that there were significant alterations of 5-hmC in SLE patients. Thus, these differentially hydroxymethylated genes may contribute to the pathogenesis of SLE. These findings show the significance of 5-hmC as a potential biomarker or promising target for epigenetic-based SLE therapies.
\end{abstract}

Correspondence to: Professor Yong Dai, Clinical Medical Research Center, the Second Clinical Medical College of Jinan University (Shenzhen People's Hospital), No. 1017 Dongmen North Road, Shenzhen, Guangdong 518020, P.R. China

E-mail: daiyong2222@gmail.com

${ }^{*}$ Contributed equally

Key words: epigenetics, hMeDIP-chip, 5-hydroxymethylcytosine, 5-methylcytosine, systemic lupus erythematosus

\section{Introduction}

Systemic lupus erythematosus (SLE) is a typical systemic autoimmune disease, involving diffuse connective tissues (1) and is characterized by immune inflammation. SLE has a complex pathogenesis (2), involving genetic, immunologic and environmental factors. Thus, it may result in damage to multiple tissues and organs, especially the kidneys (3). SLE arises from a combination of heritable and environmental influences.

Epigenetics, the study of changes in gene expression that occur without changes in the DNA sequence, have been suggested to underlie age-related dysfunction and associated disorders (5). The major epigenetic mechanisms include DNA methylation, histone modifications and microRNAs. Recent findings (4) have shown that epigenetic abnormalities are closely correlated with the pathogenesis of SLE. Epigenetic studies may provide clues to elucidate the pathogenesis of SLE and develop new strategies to treat this disease.

DNA hydroxymethylation (5-hydroxymethylcytosine, 5 -hmC) $(6,7)$ is a newly described epigenetic modification. It is an oxidative product of the well-known DNA methylation (5-methylcytosine, 5-mC) and catalyzed by the ten eleven translocation (TET) family of enzymes (8), a family of enzymes dependent on 2-oxoglutarate and $\mathrm{Fe}(\mathrm{II})$ in vitro and in vivo.

The methylation of cytosine-guanine dinucleotides $(\mathrm{CpG})$ with $\mathrm{C}(9)$ is a common epigenetic modification in mammals and is also widespread in animals and plants. As an important epigenetic modification, 5-mC regulates genomic functions, such as gene transcription, $\mathrm{X}$-chromosome inactivation, imprinting, genetic mutation and chromosome stability (10-12). 5-mC is only one component of a dynamic epigenetic regulatory network of DNA modifications that also includes 5-hmC, 5-formylcytosine and 5-carboxylcytosine. The reversible methylation of N6-methyladenosine in RNA has also been demonstrated (13).

5-hmC was first found in bacteriophage DNA in 1952. It was utilized several decades ago, only after its recent identification in DNA from murine brain and stem cells rendered 5-hmC a major focus of epigenomic investigations (14). The lower affinity of methyl-binding proteins to 5-hmC compared with 5-mC suggests that this modification may have a distinct 
role in gene expression regulation. However, 5-hmC is also involved in the DNA demethylation process $(15,16)$.

To obtain a deeper understanding of the role of 5-hmC with regard to the onset of SLE, we generated genome-wide maps of 5-hmC in patients with SLE and healthy controls by performing hydroxymethyl-DNA immunoprecipitation followed by massively parallel sequencing with an Illumina Genome Analyzer (hMeDIP-chip).

\section{Materials and methods}

Patients and controls. Whole blood samples from 15 SLE patients and 15 normal controls were obtained from the 181st Hospital of Guilin (China), between January and September, 2011. The SLE diagnoses were confirmed based on pathology and clinical evidence following the American Rheumatism Association classification criteria (1987).

Written informed consent was obtained from all the subjects or their guardians. The use of biopsy material for studies beyond routine diagnosis was approved by the local ethics committee. This study abides by the Helsinki Declaration on ethical principles for medical research involving human subjects.

Genomic DNA extraction and fragmentation. Blood samples were obtained from SLE patients $(n=15,5 \mu 1$ per subject pooled into one blood sample) and normal controls $(n=15$, $5 \mu$ per subject pooled into one blood sample). Genomic DNA (gDNA) was extracted from the SLE patients and normal control blood samples using a DNeasy Blood \& Tissue kit (Qiagen, Fremont, CA, USA). The purified gDNA was then quantified and its quality assessed using a Nanodrop ND-1000 (Table I). The genomic DNA from each sample pool was sonicated to $200-1000$ bp using a Bioruptor sonicator (Diagenode, Denville, NJ, USA) on the 'Low' setting for 10 cycles of $30 \mathrm{sec}$ 'ON' and $30 \mathrm{sec}$ 'OFF'. The gDNA and each sheared DNA sample were analyzed on an agarose gel.

GO analysis of differentially expressed 5-hmC. To investigate the specific functions of the differentially expressed 5 -hmC in the developmental process of SLE, the 5-hmC targets of each differentially expressed 5 -hmC were identified by GO categories. The GO categories are derived from gene ontology, which comprise three structured networks of defined terms that describe gene product attributes.

Pathway analysis of differentially expressed 5-hmC. Pathway analysis is a functional analysis mapping genes to KEGG pathways. To evaluate the effect of SNP-to-gene mapping strategy on pathway analysis, we also mapped SNPs to genes within differentially expressed $5-\mathrm{hmC}$.

Immunoprecipitation. One microgram of the sonicated genomic DNA was used for immunoprecipitation using a mouse monoclonal anti-5-hydroxymethylcytosine antibody (Diagenode). Prior to immunoprecipitation, the spike-in control sequences were mixed with the genomic DNA fragments. The DNA was then heat-denatured at $94^{\circ} \mathrm{C}$ for $10 \mathrm{~min}$, rapidly cooled on ice, and immunoprecipitated with $1 \mu \mathrm{l}$ of primary antibody overnight at $4{ }^{\circ} \mathrm{C}$ with rocking agitation in $400 \mu \mathrm{l}$ of immunoprecipitation buffer (0.5\% BSA in PBS).
To recover the immunoprecipitated DNA fragments, $200 \mu \mathrm{l}$ of anti-mouse IgG magnetic beads were added and incubated for an additional $2 \mathrm{~h}$ at $4^{\circ} \mathrm{C}$ with agitation. After immunoprecipitation, a total of five immunoprecipitation washes were performed with ice-cold immunoprecipitation buffer. The washed beads were resuspended in TE buffer with $0.25 \%$ SDS and $0.25 \mathrm{mg} / \mathrm{ml}$ proteinase $\mathrm{K}$ for $2 \mathrm{~h}$ at $65^{\circ} \mathrm{C}$ and then allowed to cool to room temperature. The hMeDIP DNA fragments were purified using Qiagen MinElute columns (Qiagen).

DNA labeling and array hybridization. For DNA labeling, the NimbleGen Dual-Color DNA Labeling kit was used according to the manufacturer's instructions as detailed in the NimbleGen hMeDIP-chip protocol (NimbleGen Systems, Inc., Madison, WI, USA). DNA ( $1 \mu \mathrm{g})$ from each sample was incubated for $10 \mathrm{~min}$ at $98^{\circ} \mathrm{C}$ with $1 \mathrm{OD}$ of Cy5-9mer primer (IP sample) or Cy3-9mer primer (Input sample). Then, 100 pmol of deoxynucleoside triphosphates and 100 units of the Klenow fragment (New England Biolabs, Beverly, MA, USA) were added, and the mixture was incubated at $37^{\circ} \mathrm{C}$ for $2 \mathrm{~h}$. The reaction was stopped by adding $0.1 \mathrm{X}$ volume of 0.5 MEDTA, and the labeled DNA was purified by isopropanol/ethanol precipitation. The microarrays were hybridized at $42^{\circ} \mathrm{C}$ for 16-20 h with Cy3/5-labeled DNA in Nimblegen hybridization buffer/ hybridization component A in a hybridization chamber (Hybridization System - Nimblegen Systems, Inc.). Following hybridization, washing was performed using the Nimblegen Wash Buffer kit (Nimblegen Systems, Inc.). For array hybridization, Roche NimbleGen's Promoter plus CpG Island Array was used, which is a $385 \mathrm{~K}$ array containing $28,226 \mathrm{CpG}$ islands and well-characterized promoter regions (approximately -800 to +200 bp relative to the TSSs) that were completely covered by $\sim 385,000$ probes.

Quantitative RT-PCR verification of 5-hmC. The DNA was reverse transcribed to cDNA using gene-specific primers (Table II). The cycle parameters for the PCR reactions were $95^{\circ} \mathrm{C}$ for $10 \mathrm{~min}$ followed by 40 cycles of a denaturing step at $95^{\circ} \mathrm{C}$ for $10 \mathrm{sec}$ and an annealing/extension step at $60^{\circ} \mathrm{C}$ for $60 \mathrm{sec}$. The relative amount of each gene was described using the equation $2-\Delta \mathrm{Ct}$, where $\Delta \mathrm{Ct}=(\mathrm{CtmRNA}-\mathrm{CtU} 6)$. The genes analyzed included TREX1, CDKN1A and CDKN1B.

\section{Results}

hMeDIP-chip. Using specific antibodies, we performed hMeDIP-chip (17) on two samples: SLE patients and normal controls. To determine the 5-hmC status of a comprehensive set of human promoters, we enriched the DNA from whole blood samples for hydroxymethylated DNA using hMeDIP-chip methodology combined with microarray detection. The selected platform was a single array design that included 28,226 CpG islands and all the Ref gene promoter regions (approximately -800 to +200 bp relative to the TSSs) that were completely covered by $\sim 385,000$ probes. The median probe spacing was $101 \mathrm{bp}$.

DMR analysis using the MEDME method. To accurately quantify the $\mathrm{CpG} 5$-hmC levels, we used a new analytical methodology, MEDME (modeling experimental data with 
Table I. DNA quantification and quality assurance by NanoDrop spectrophotometer.

\begin{tabular}{lccccc}
\hline $\begin{array}{l}\text { Sample } \\
\text { ID }\end{array}$ & $\begin{array}{c}\text { OD260/2 } \\
80 \text { ratio }\end{array}$ & $\begin{array}{c}\text { OD260/2 } \\
30 \text { ratio }\end{array}$ & $\begin{array}{c}\text { Conc. } \\
(\mathrm{ng} / \mu \mathrm{l})\end{array}$ & $\begin{array}{c}\text { Volume } \\
(\mu \mathrm{l})\end{array}$ & $\begin{array}{c}\text { Total amount } \\
(\mathrm{ng})\end{array}$ \\
\hline Control & 1.81 & 2.05 & 41.60 & 100 & 4160.00 \\
SLE & 1.63 & 1.89 & 32.38 & 100 & 3238.00 \\
\hline
\end{tabular}

For spectrophotometer, the optical density (OD) A260/A280 ratio was required to be close to 1.8 for pure DNA (ratios between 1.7 and 2.0 were acceptable). The OD A260/A230 ratio was required to be $>1.8$.

Table II. Reverse-transcription and RT-qPCR primers.

\begin{tabular}{llcc} 
Gene name & \multicolumn{1}{c}{ RT-qPCR primers } & $\begin{array}{c}\text { Annealing } \\
\text { temperature }\left({ }^{\circ} \mathrm{C}\right)\end{array}$ & $\begin{array}{c}\text { Product length } \\
\text { (bp) }\end{array}$ \\
\hline TREX1 & F: 5'-GTGTTCCAAGTGCTGCCAAA-3' & & 245 \\
CDKN1A & R: 5'-CATAAAGAGCGTGGGCTACATAC-3' & 60 & 207 \\
CDKN1B & F: 5'-AGCCTTCCTCACATCCTCCTT-3' & 60 & 224 \\
& R: 5'-GACGGCCAGAAAGCCAATC-3' & & \\
\hline
\end{tabular}

F, forward; R, reverse.

hMeDIP enrichment), to improve the evaluation and interpretation of the hMeDIP-derived 5-hmC estimates. MEDME utilizes the absolute 5-hmC score (AHS) as the value for DNA hydroxymethylation, which is calculated based on the weighted count of the hydroxymethylated $\mathrm{CpG}$ dinucleotides in a $1 \mathrm{~kb}$ window centered at each probe. The AHS has been verified to be a more accurate and sensitive measurement of 5-hmC levels than the log-ratio. The MEDME method also provides a relative 5-hmC score (RHS) that normalizes the AHS to the total number of $\mathrm{CpGs}$ represented by $\mathrm{CpGw}$. This method allows investigators to obtain a relative measurement of the 5-hmC that is independent of the $\mathrm{CpG}$ density of the corresponding region. The RMS is especially useful when comparing regions with different $\mathrm{CpG}$ densities.

Promoter classes in relation to $C p G$ frequency. Approximately $70 \%$ of human genes are associated with promoter $\mathrm{CpG}$ islands, whereas the remaining promoters tend to be depleted in CpGs. The presence of 5-hmC in promoter regions is associated with high levels of transcription, which is consistent with a role for 5-hmC in the maintenance and promotion of gene expression. This effect is also partially dependent on the $\mathrm{CpG}$ density of the promoter. Based on the $\mathrm{CpG}$ density, the $\mathrm{CpG}$ ratio and length of the $\mathrm{CpG}$-rich region, the promoters are subdivided into three classes: high (HCP), low (LCP), and intermediate (ICP) $\mathrm{CpG}$ density.

These classes are defined as follows: i) High-CpG-density promoters $(\mathrm{HCP})$ are promoters containing a 500-bp interval within the region from $0.7 \mathrm{~kb}$ upstream to $0.2 \mathrm{~kb}$ downstream of the TSS with a GC percentage $\geq 55 \%$ and a $\mathrm{CpG}$ observedto-expected ratio $(\mathrm{O} / \mathrm{E}) \geq 0.6$. ii) Low-CpG-density promoters

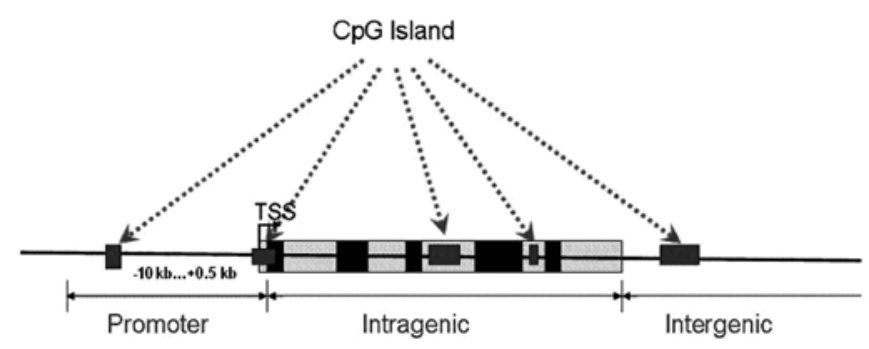

Figure 1. The definition of the relationship CPG and the transcription region.

(LCP) are promoters containing no $500 \mathrm{bp}$ interval with a $\mathrm{CpG} \mathrm{O} / \mathrm{E} \geq 0.4$. iii) Intermediate-CpG-density promoters (ICP) include the remaining promoters that were not classified as HCP or LCP.

CpG island 5-hmC. Mammalian genomes are punctuated by DNA sequences that contain an atypically high frequency of $\mathrm{CpG}$ sites termed $\mathrm{CpG}$ islands (CGIs). These sequences are characterized as $\geq 200 \mathrm{bp}$ in length with a GC content of $50 \%$ and a $\mathrm{CpG} \mathrm{O/E}$ of 0.6 .

$\mathrm{CpG}$ islands can be grouped into three classes based on their distance to RefSeq annotated genes: i) Promoter islands occur from approximately -10 to $+0.5 \mathrm{~kb}$ around the transcription start site. ii) Intragenic islands occur from $0.5 \mathrm{~kb}$ downstream of the transcription start site to the site of transcription termination. iii) Intergenic islands include all other $\mathrm{CpG}$ islands that were not classified as being in the promoter or intragenic category (Fig. 1). 


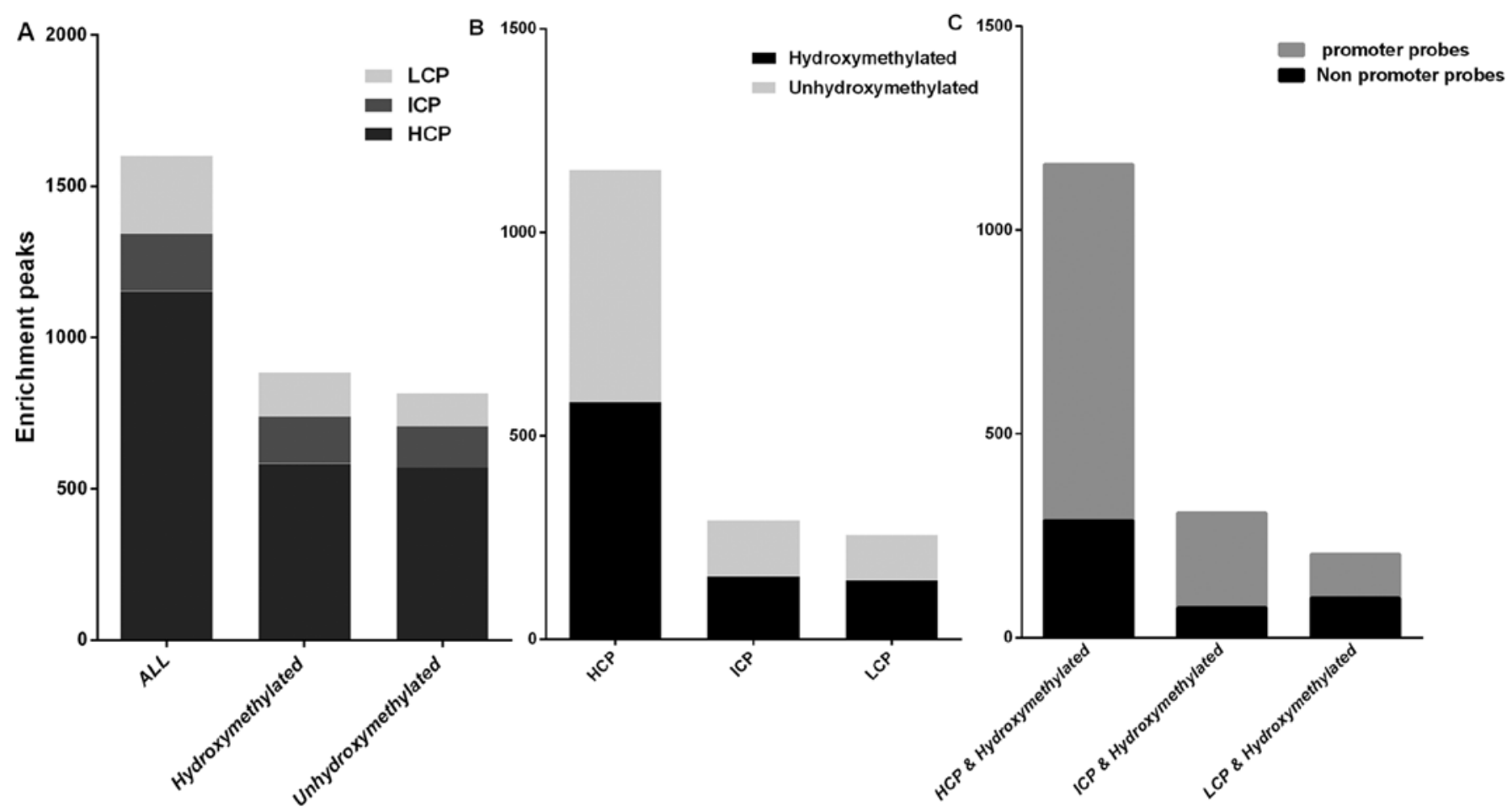

Figure 2. DNA 385K promoter of hydroxymethylated and unhydroxymethylated promoters compared between the SLE patients and the normal controls. (A) Classification of all, hydroxymethylated, or unhydroxymethylated promoters with high (HCP), intermediate (ICP), and low (LCP) CpG content. (B) Breakdown of hydroxymethylation status for HCP, ICP, and LCP promoters. (C) Percentage of genes with hydroxymethylated promoters in $\mathrm{CpG}$ islands.

Genome-wide profiling of promoter DNA 5-hmC. Based on the data obtained, we examined the $\mathrm{CpG}$ content in the pool of hydroxymethylated promoters compared to non-hydroxymethylated promoters that exhibited significant differences in 5-hmC levels between the SLE patients and normal controls. We found that $65.95 \%$ of hydroxymethylated genes belonged to the HCP cluster, which is similar to the average occurrence of HCP genes genome-wide (67.82\%) (Fig. 2A). Similarly, $69.85 \%$ of the non-hydroxymethylated genes were associated with HCPs (Fig. 2A). A detailed analysis of the distribution of the hydroxymethylated probes over these promoters, which contained at least one $\mathrm{CpG}$ island by definition, indicated that $75.21 \%$ of the HCP genes had a hydroxymethylated probe that overlapped with the $\mathrm{CpG}$ island itself (Figs. 1 and 2C). By contrast, $\sim 45 \%$ of the ICP and LCP genes were characterized as hydroxymethylated genes (Fig. 2B). We conclude that DNA hydroxymethylation in the blood of SLE patients primarily occurs at $\mathrm{HCP}$ promoters or at nonpromoter- $\mathrm{CpG}$ islands within HCP genes.

GO analysis of differentially expressed 5-hmC. To investigate the specific functions of the differentially expressed $5-\mathrm{hmC}$ in the developmental process of SLE, the 5-hmC targets of each differentially expressed 5 -hmC were identified by $\mathrm{GO}$ categories. The GO categories were derived from gene ontology, comprising three structured networks of defined terms that describe gene product attributes. The P-value denotes the significance of GO term enrichment in the differentially expressed 5-hmC list. Thus, the lower the P-value, the more significant the GO term, with $\mathrm{P} \leq 0.05$ being recommended.
In terms of the GO database, the differentially expressed proteins encoded by these genes were divided into three categories: biological process, cell component and molecular function (Fig. 3). Through GO analysis for differentially expressed $5-h m C$ genes, we found that 71 differentially expressed $5-h m C$ genes with annotation terms being linked to the GO biological process categories, 30 being linked to the cell component and 20 being linked to the molecular function, with $\mathrm{P}<0.01$. Details of the cell component categories, molecular function ontology, biological process ontology are presented in Table III.

Pathway analysis of differentially expressed 5-hmC. Pathway analysis is a functional analysis mapping genes to KEGG pathways. The P-value (EASE-score, Fisher P-value or Hypergeometric P-value) denotes the significance of the pathway correlated with the following conditions: the lower the $\mathrm{P}$-value, the more significant the pathway, with $\mathrm{P}=0.05$ as the cut-off value. In order to evaluate the influence of SNP-togene mapping strategy on the pathway analysis, we mapped SNPs to genes within differentially expressed 5-hmC.

In terms of the Pathway database, 17 pathways were significant $(\mathrm{P}<0.05)$. Differentially expressed $5-\mathrm{hmC}$ is shown in Fig. 4, while details of the pathways are present in Table IV. Furthermore, the $C D K N 1 A$ and $C D K N 1 B$ genes contributed to the $\operatorname{ErbB}(\mathrm{P}=0.01073062), \mathrm{P} 13-\mathrm{Akt}(\mathrm{P}=0.04341327)$, and HIF-1 ( $\mathrm{P}=0.04345306)$ signaling pathways.

Comparison of 5-hmC status between SLE patients and normal controls. By applying the analysis procedure described 
A

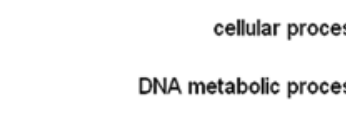

neurotransmitter biosynthetic process

localization

cellular response to stress

cellular component organization

cell death

death

cellular component organization or biogenesis

nitrogen compound transport

$-\log 10($ P-value)

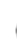

B

intracellular part
intracellular
cytoplasm
organelle

intracellular organelle

cytoplasmic part

membrane-bounded organelle

intracellular membrane-bounded organelle

nucleus
organelle part

nucleus
organelle part
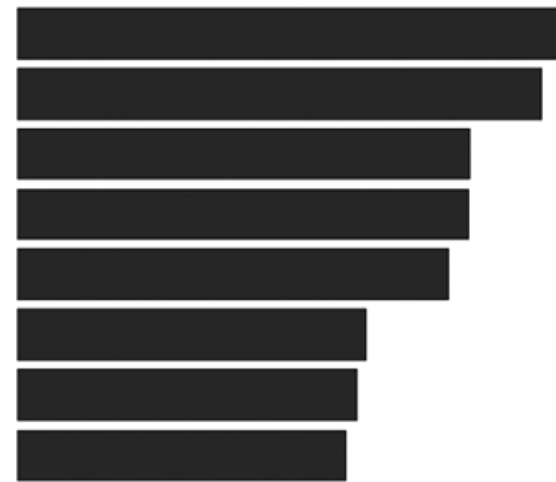

$-\log 10$ (P-value)
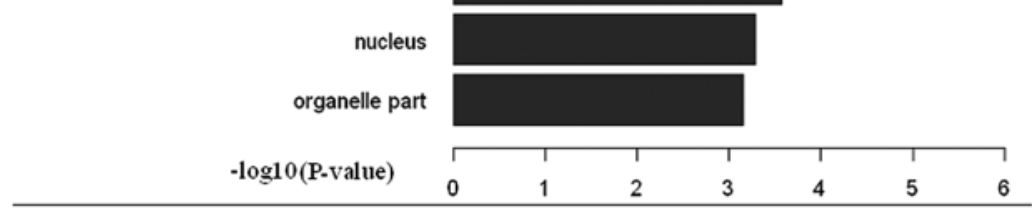

C

binding

protein binding

protein phosphatase type $2 \mathrm{~A}$ regulator activity

amine transmembrane transporter activity

carboxylic acid transmembrane transporter activity

ferrous iron binding

small GTPase binding

coenzyme binding

organic acid transmembrane transporter activity

protein phosphatase binding

- $\log 10$ (P-value)

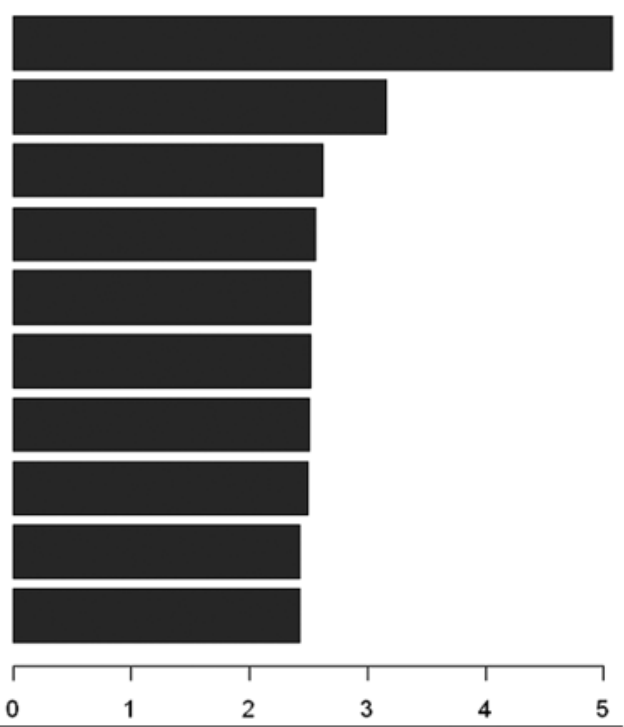

Figure 3. (A) Signal GO term of differentially expressed genes in biological process. (B) Signal GO term of differentially expressed genes in cellular component. (C) Signal GO term of differentially expressed genes in molecular function.

above to the sequencing results, we found that 1,701 gene promoter regions showed significantly different levels of 5-hmC in the SLE patients compared with the normal controls.
Of these genes, 884 exhibited increased 5-hmC and 817 exhibited decreased 5-hmC (Fig. 5A). The CpG islands of 3,826 genes showed significant differences in 5-hmC levels in 
Table III. Functional analysis of genetic differences of 5-hmC $(\mathrm{P}<0.01)$.

\begin{tabular}{|c|c|c|c|c|}
\hline GO ID & Term & $\begin{array}{l}\text { Gene } \\
(\mathrm{n})\end{array}$ & P-value & $\begin{array}{c}\text { Enrichment } \\
\text { score }\end{array}$ \\
\hline \multicolumn{5}{|c|}{ Molecular function } \\
\hline GO:0005488 & Binding & 975 & $8.47676 \mathrm{E}-06$ & 5.071770331 \\
\hline GO:0005515 & Protein binding & 574 & 0.0006979 & 3.156206958 \\
\hline GO:0008601 & Protein phosphatase type $2 \mathrm{~A}$ regulator activity & 6 & 0.002390223 & 2.621561587 \\
\hline GO:0005275 & Amine transmembrane transporter activity & 14 & 0.002741565 & 2.562001469 \\
\hline GO:0046943 & Carboxylic acid transmembrane transporter activity & 16 & 0.003032561 & 2.518190484 \\
\hline GO:0008198 & Ferrous iron binding & 5 & 0.003048552 & 2.515906422 \\
\hline GO:0031267 & Small GTPase binding & 19 & 0.003112164 & 2.506937561 \\
\hline GO:0050662 & Coenzyme binding & 26 & 0.003164007 & 2.499762629 \\
\hline GO:0005342 & Organic acid transmembrane transporter activity & 16 & 0.003738627 & 2.427287911 \\
\hline GO:0019903 & Protein phosphatase binding & 12 & 0.003795492 & 2.420731959 \\
\hline GO:0004683 & Calmodulin-dependent protein kinase activity & 6 & 0.004182328 & 2.37858187 \\
\hline GO:0015248 & Sterol transporter activity & 5 & 0.004284399 & 2.368110104 \\
\hline GO:0015370 & Solute:sodium symporter activity & 10 & 0.005096459 & 2.292731449 \\
\hline GO:0015293 & Symporter activity & 19 & 0.005283676 & 2.277063859 \\
\hline GO:0003677 & DNA binding & 210 & 0.00545348 & 2.263326261 \\
\hline GO:0017016 & Ras GTPase binding & 17 & 0.005511619 & 2.258720783 \\
\hline GO:0003676 & Nucleic acid binding & 290 & 0.005672365 & 2.246235825 \\
\hline GO:0036094 & Small molecule binding & 229 & 0.00603527 & 2.219303294 \\
\hline GO:0000166 & Nucleotide binding & 215 & 0.006277361 & 2.202222878 \\
\hline GO:0019902 & Phosphatase binding & 15 & 0.008158707 & 2.088378687 \\
\hline \multicolumn{5}{|c|}{ Cellular component } \\
\hline GO:0044424 & Intracellular component & 991 & $1.25802 \mathrm{E}-06$ & 5.900311838 \\
\hline GO:0005622 & Intracellular & 1011 & $1.96706 \mathrm{E}-06$ & 5.706182597 \\
\hline GO:0005737 & Cytoplasm & 751 & 1.1809E-05 & 4.927788392 \\
\hline GO:0043226 & Organelle & 863 & $1.23569 \mathrm{E}-05$ & 4.908089407 \\
\hline GO:0043229 & Intracellular organelle & 860 & $2.02157 \mathrm{E}-05$ & 4.694310928 \\
\hline GO:0044444 & Cytoplasmic component & 556 & 0.000162517 & 3.789099975 \\
\hline GO:0043227 & Membrane-bound organelle & 773 & 0.000201161 & 3.696456379 \\
\hline GO:0043231 & Intracellular membrane-bound organelle & 771 & 0.000263573 & 3.579099179 \\
\hline GO:0005634 & Nucleus & 503 & 0.000511564 & 3.291100377 \\
\hline GO:0044422 & Organelle component & 518 & 0.000698363 & 3.155918681 \\
\hline GO:0044446 & Intracellular organelle component & 511 & 0.000826581 & 3.082714383 \\
\hline GO:0005815 & Microtubule organizing center & 54 & 0.001500698 & 2.823706722 \\
\hline GO:0044464 & Cell component & 1146 & 0.001599278 & 2.79607593 \\
\hline GO:0005623 & Cell & 1146 & 0.00163091 & 2.78757007 \\
\hline GO:0015630 & Microtubule cytoskeleton & 86 & 0.001672538 & 2.776623893 \\
\hline GO:0031988 & Membrane-bound vesicle & 85 & 0.002151442 & 2.667270359 \\
\hline GO:0000159 & Protein phosphatase type $2 \mathrm{~A}$ complex & 6 & 0.002383019 & 2.622872453 \\
\hline GO:0005856 & Cytoskeleton & 163 & 0.002653136 & 2.576240518 \\
\hline GO:0030312 & External encapsulating structure & 5 & 0.003040318 & 2.517080953 \\
\hline GO:0016023 & Cytoplasmic membrane-bound vesicle & 82 & 0.003540727 & 2.450907507 \\
\hline GO:0031410 & Cytoplasmic vesicle & 85 & 0.005938359 & 2.226333534 \\
\hline GO:0044428 & Nuclear component & 215 & 0.006110243 & 2.213941539 \\
\hline GO:0043228 & Non-membrane-bound organelle & 265 & 0.006188271 & 2.208430644 \\
\hline GO:0043232 & Intracellular non-membrane-bound organelle & 265 & 0.006188271 & 2.208430644 \\
\hline GO:0031982 & Vesicle & 88 & 0.006466493 & 2.189331194 \\
\hline GO:0005874 & Microtubule & 37 & 0.007122082 & 2.147393031 \\
\hline GO:0043240 & Fanconi anaemia nuclear complex & 4 & 0.007554527 & 2.12179274 \\
\hline GO:0005829 & Cytosol & 201 & 0.007559368 & 2.121514538 \\
\hline GO:0008328 & Ionotropic glutamate receptor complex & 6 & 0.008472321 & 2.071997622 \\
\hline GO:0031974 & Membrane-enclosed lumen & 228 & 0.009528722 & 2.020965349 \\
\hline
\end{tabular}


Table III. Continued.

\begin{tabular}{|c|c|c|c|c|}
\hline GO ID & Term & $\begin{array}{l}\text { Gene } \\
(n)\end{array}$ & P-value & $\begin{array}{l}\text { Enrichment } \\
\text { score }\end{array}$ \\
\hline \multicolumn{5}{|c|}{ Biological process } \\
\hline GO:0009987 & Cell process & 1046 & 4.20173E-07 & 6.376571542 \\
\hline GO:0006259 & DNA metabolic process & 93 & 0.000371782 & 3.429711695 \\
\hline GO:0042136 & Neurotransmitter biosynthetic process & 6 & 0.000405199 & 3.392331799 \\
\hline GO:0051179 & Localization & 374 & 0.000503121 & 3.2983276 \\
\hline GO:0033554 & Cell response to stress & 114 & 0.000534186 & 3.272307489 \\
\hline GO:0016043 & Cell component organization & 344 & 0.000617972 & 3.209030892 \\
\hline GO:0008219 & Cell death & 166 & 0.000636118 & 3.19646263 \\
\hline GO:0016265 & Death & 166 & 0.000672212 & 3.172493732 \\
\hline GO:0071840 & Cell component organization or biogenesis & 352 & 0.000808943 & 3.092082017 \\
\hline GO:0071705 & Nitrogen compound transport & 29 & 0.000836139 & 3.077721402 \\
\hline GO:0010950 & Positive regulation of endopeptidase activity & 18 & 0.000934594 & 3.029376965 \\
\hline GO:0012501 & Programmed cell death & 152 & 0.000944228 & 3.024923241 \\
\hline GO:0071702 & Organic substance transport & 59 & 0.001039557 & 2.983151486 \\
\hline GO:0021987 & Ccerebral cortex development & 12 & 0.001156639 & 2.9368022 \\
\hline GO:0006915 & Apoptotic process & 150 & 0.001275381 & 2.894360003 \\
\hline GO:0015697 & Quaternary ammonium group transport & 6 & 0.001359721 & 2.866550106 \\
\hline GO:0006308 & DNA catabolic process & 13 & 0.001439981 & 2.841643257 \\
\hline GO:0010952 & Positive regulation of peptidase activity & 18 & 0.001648322 & 2.782957883 \\
\hline GO:0030301 & Cholesterol transport & 12 & 0.001863628 & 2.729640865 \\
\hline GO:0015918 & Sterol transport & 12 & 0.002166069 & 2.664327795 \\
\hline GO:0021543 & Pallium development & 15 & 0.002411739 & 2.617669728 \\
\hline GO:0042632 & Cholesterol homeostasis & 11 & 0.00280871 & 2.551493105 \\
\hline GO:0055092 & Sterol homeostasis & 11 & 0.00280871 & 2.551493105 \\
\hline GO:0007169 & $\begin{array}{l}\text { Transmembrane receptor protein tyrosine kinase } \\
\text { signaling pathway }\end{array}$ & 66 & 0.003092099 & 2.509746586 \\
\hline GO:0006281 & DNA repair & 45 & 0.00309275 & 2.509655117 \\
\hline GO:0006919 & $\begin{array}{l}\text { Activation of cysteine-type endopeptidase } \\
\text { activity involved in apoptotic process }\end{array}$ & 14 & 0.003187141 & 2.496598699 \\
\hline GO:0097202 & Activation of cysteine-type endopeptidase activity & 14 & 0.003187141 & 2.496598699 \\
\hline GO:0007049 & Cell cycle & 131 & 0.003246836 & 2.488539594 \\
\hline GO:0006950 & Response to stress & 254 & 0.003252788 & 2.487744307 \\
\hline GO:0060317 & Cardiac epithelial to mesenchymal transition & 5 & 0.003278753 & 2.484291311 \\
\hline GO:0015837 & Amine transport & 24 & 0.003396431 & 2.468977217 \\
\hline GO:0010033 & Response to organic substance & 156 & 0.003703461 & 2.431392194 \\
\hline GO:0043280 & $\begin{array}{l}\text { Positive regulation of cysteine-type endopeptidase } \\
\text { activity involved in apoptotic process }\end{array}$ & 16 & 0.003962 & 2.402085511 \\
\hline GO:2001056 & Positive regulation of cysteine-type endopeptidase activity & 16 & 0.003962 & 2.402085511 \\
\hline GO:0010941 & Regulation of cell death & 119 & 0.004400697 & 2.35647858 \\
\hline GO:0034641 & Cellular nitrogen compound metabolic process & 465 & 0.004692655 & 2.328581332 \\
\hline GO:0008629 & Induction of apoptosis by intracellular signals & 15 & 0.004728501 & 2.32527652 \\
\hline GO:0071842 & Cellular component organization at the cellular level & 268 & 0.0048397 & 2.315181593 \\
\hline GO:0032677 & Regulation of interleukin- 8 production & 8 & 0.004962569 & 2.304293443 \\
\hline GO:0006807 & Nitrogen compound metabolic process & 473 & 0.005208958 & 2.283249159 \\
\hline GO:0042981 & Regulation of apoptotic process & 115 & 0.005273137 & 2.277930908 \\
\hline GO:0071294 & Cell response to zinc ion & 4 & 0.005446325 & 2.26389645 \\
\hline GO:0006139 & Nucleobase-containing compound metabolic process & 431 & 0.005604946 & 2.251428588 \\
\hline GO:0006810 & Transport & 302 & 0.005935568 & 2.22653772 \\
\hline GO:0071841 & $\begin{array}{l}\text { Cell component organization or biogenesis } \\
\text { at the cellular level }\end{array}$ & 275 & 0.00611302 & 2.213744154 \\
\hline GO:0051716 & Cell response to stimulus & 413 & 0.006239288 & 2.204864975 \\
\hline GO:0032365 & Intracellular lipid transport & 5 & 0.006266841 & 2.20295135 \\
\hline
\end{tabular}


Table III. Continued.

\begin{tabular}{|c|c|c|c|c|}
\hline GO ID & Term & $\begin{array}{l}\text { Gene } \\
\text { (n) }\end{array}$ & P-value & $\begin{array}{c}\text { Enrichment } \\
\text { score }\end{array}$ \\
\hline GO:0040007 & Growth & 76 & 0.006279845 & 2.20205109 \\
\hline GO:0044272 & Sulfur compound biosynthetic process & 11 & 0.006528232 & 2.185204402 \\
\hline GO:0043067 & Regulation of programmed cell death & 115 & 0.006686996 & 2.174768905 \\
\hline GO:0007167 & Enzyme-linked receptor protein signaling pathway & 83 & 0.006693713 & 2.174332938 \\
\hline GO:0030168 & Platelet activation & 28 & 0.007338694 & 2.134381237 \\
\hline GO:0015695 & Organic cation transport & 7 & 0.007484604 & 2.125831149 \\
\hline GO:0014066 & Regulation of phosphatidylinositol 3-kinase cascade & 9 & 0.007501308 & 2.124863025 \\
\hline GO:0050794 & Regulation of the cell process & 631 & 0.007609603 & 2.118638012 \\
\hline GO:0044260 & Cellular macromolecule metabolic process & 530 & 0.007722583 & 2.11223743 \\
\hline GO:0042157 & Lipoprotein metabolic process & 15 & 0.00781696 & 2.10696213 \\
\hline GO:0051234 & Establishment of localization & 305 & 0.007999858 & 2.096917735 \\
\hline GO:0003203 & Endocardial cushion morphogenesis & 4 & 0.008030603 & 2.095251834 \\
\hline GO:0042149 & Cell response to glucose starvation & 4 & 0.008030603 & 2.095251834 \\
\hline GO:0045540 & Regulation of cholesterol biosynthetic process & 4 & 0.008030603 & 2.095251834 \\
\hline GO:0043065 & Positive regulation of apoptotic process & 61 & 0.008093257 & 2.091876684 \\
\hline GO:0035556 & Intracellular signal transduction & 173 & 0.008130715 & 2.089871248 \\
\hline GO:0032637 & Interleukin-8 production & 8 & 0.008361973 & 2.077691232 \\
\hline GO:0090304 & Nucleic acid metabolic process & 365 & 0.00864538 & 2.063215898 \\
\hline GO:0046686 & Response to cadmium ion & 7 & 0.009025274 & 2.044539606 \\
\hline GO:0006586 & Indolalkylamine metabolic process & 6 & 0.009194049 & 2.036493163 \\
\hline GO:0009225 & Nucleotide-sugar metabolic process & 6 & 0.009194049 & 2.036493163 \\
\hline GO:0042430 & Indole-containing compound metabolic process & 6 & 0.009194049 & 2.036493163 \\
\hline GO:0006974 & Response to DNA damage stimulus & 61 & 0.009681709 & 2.014047956 \\
\hline GO:0043068 & Positive regulation of programmed cell death & 61 & 0.009681709 & 2.014047956 \\
\hline
\end{tabular}

GO ID, the ID of gene ontology terms used in the Gene Ontology Project; Term, the name of the gene ontology term; Enrichment score, the enrichment score value of GO ID, which equals [- $\log 10$ (P-value)]; P-value, the significance testing value of the GOID, result from the topGO of bioconductor. If the P-value is lower than 1e-299, the P-value will be adjusted as the value of 1e-299.

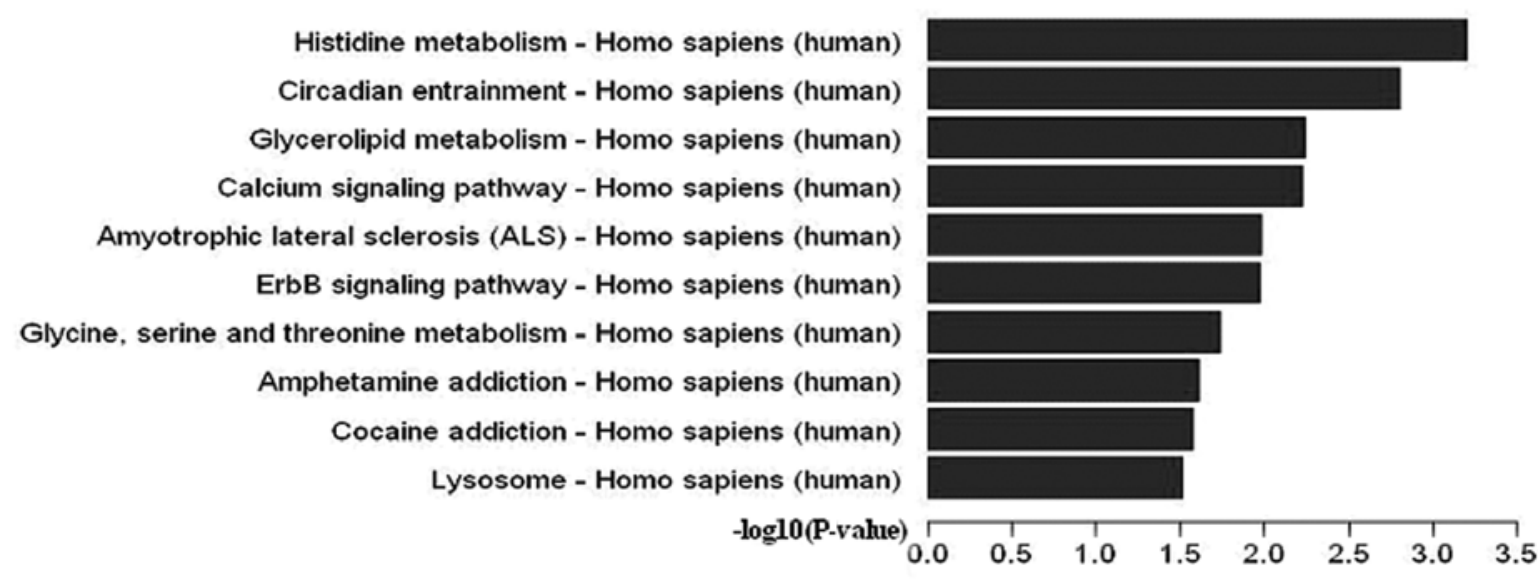

Figure 4. Pathway barplot explanation of differentially expressed genes.

the SLE patients compared with the normal controls. Of these genes, 2,034 exhibited increased 5-hmC and 1,792 exhibited decreased 5-hmC (Fig. 5B).

Pie chart A shows the chromosomal locations of the 884 genes that were hyper-hydroxymethylated within the promoter region in the SLE patients compared with the normal controls (clockwise from chromosome 1 to the $\mathrm{X}$ and Y sex chromosomes). The percentage of genes hyper-hydroxymethylated on chromosome 1 was $10 \%$ (Fig. 6A). Pie chart B shows the chromosomal locations of the 2,034 genes that were 
Table IV. Transduction pathway analysis in 5-hmC differences genes.

\begin{tabular}{|c|c|c|c|c|}
\hline $\begin{array}{l}\text { KEGG } \\
\text { Pathways }\end{array}$ & $\begin{array}{l}\text { Fisher } \\
\text { (n) }\end{array}$ & $\begin{array}{c}\text { Gene } \\
\text { P-value }\end{array}$ & $\begin{array}{l}\text { Enrichment } \\
\text { score }\end{array}$ & Genes \\
\hline $\begin{array}{l}\text { Histidine metabolism - } \\
\text { Homo sapiens }\end{array}$ & 0.000632576 & 8 & 3.198888 & $\begin{array}{l}A C Y 3, A L D H 1 B 1, A L D H 3 A 2, A L D H 3 B 1, \\
H A L, H E M K 1, M A O A, W B S C R 22\end{array}$ \\
\hline $\begin{array}{l}\text { Circadian entrainment - } \\
\text { Homo sapiens }\end{array}$ & 0.001569437 & 16 & 2.804256 & $\begin{array}{l}\text { ADCY4, ADCYAP1R1, CACNAIG, } \\
C A M K 2 D, G N A S, G N G 13, G R I A 1, \\
\text { GRIN2A, GRIN2C, GRIN2D, KCNJ5, } \\
\text { MAPK1, NOS1, PER1, PRKG1, RYR2 }\end{array}$ \\
\hline $\begin{array}{l}\text { Glycerolipid metabolism - } \\
\text { Homo sapiens }\end{array}$ & 0.005711304 & 10 & 2.243265 & $\begin{array}{l}A G P A T 3, A L D H 1 B 1, A L D H 3 A 2, \\
C E L, D G K H, D G K Q, D G K Z, \\
G P A M, L I P G, P P A P 2 A\end{array}$ \\
\hline $\begin{array}{l}\text { Calcium signaling } \\
\text { pathway - Homo sapiens }\end{array}$ & 0.005990646 & 23 & 2.222526 & $\begin{array}{l}\text { ADCY4, ADRA1D, ADRB2, ATP2B3, } \\
C A C N A 1 G, C A M K 2 D, C A M K 4, C D 38, \\
C Y S L-T R 1, E G F R, G N A S, G R I N 2 A, \\
\text { GRIN2C, GRIN2D, HTR7, MYLK2, } \\
\text { MYLK3, NOS1, P2RX1, PDE1B, } \\
\text { PHKG2, PLCD4, RYR2 }\end{array}$ \\
\hline $\begin{array}{l}\text { Amyotrophic lateral sclerosis } \\
\text { (ALS) - Homo sapiens }\end{array}$ & 0.0104193 & 9 & 1.982162 & $\begin{array}{l}\text { APAF1, CYCS , DERL1, GRIA1, } \\
\text { GRIN2A, GRIN2C, GRIN2D, NEFH, NOS1 }\end{array}$ \\
\hline $\begin{array}{l}\text { ErbB signaling pathway - } \\
\text { Homo sapiens }\end{array}$ & 0.01073062 & 13 & 1.969375 & $\begin{array}{l}C A M K 2 D, C D K N 1 A, C D K N 1 B, C R K, \\
C R K L, E G F R, E L K 1, M A P K 1, N C K 1, \\
N R G 2, N R G 3, P I K 3 R 3, P T K 2\end{array}$ \\
\hline $\begin{array}{l}\text { Glycine, serine and threonine } \\
\text { metabolism - Homo sapiens }\end{array}$ & 0.01823201 & 7 & 1.739166 & $\begin{array}{l}\text { BHMT, CTH, DAO, GNMT, } \\
M A O A, P S P H, S D S L\end{array}$ \\
\hline $\begin{array}{l}\text { Amphetamine addiction - } \\
\text { Homo sapiens }\end{array}$ & 0.02439724 & 10 & 1.612659 & $\begin{array}{l}\text { CAMK2D, CAMK4, CREB3L2, } \\
\text { GNAS, GRIA1, GRIN2A, GRIN2C, } \\
\text { GRIN2D, MAOA,TH }\end{array}$ \\
\hline $\begin{array}{l}\text { Cocaine addiction - } \\
\text { Homo sapiens }\end{array}$ & 0.02669436 & 8 & 1.57358 & $\begin{array}{l}\text { BDNF, CREB3L2, GNAS, GRIN2A, } \\
\text { GRIN2C, GRIN2D, MAOA,TH }\end{array}$ \\
\hline $\begin{array}{l}\text { Lysosome - } \\
\text { Homo sapiens }\end{array}$ & 0.03098124 & 15 & 1.508901 & $\begin{array}{l}A B C A 2, A P 3 M 1, A P 3 S 2, A P 4 B 1, A R S A, \\
A T P 6 V O B, A T P 6 V 1 H, C L T A, C T N S, \\
C T S L 2, H E X B, I G F 2 R, N P C 1, \\
\text { NPC2, SLC17-A5 }\end{array}$ \\
\hline $\begin{array}{l}\text { Glycerophospholipid } \\
\text { metabolism - } \\
\text { Homo sapiens }\end{array}$ & 0.03160531 & 12 & 1.50024 & $\begin{array}{l}\text { AGPAT3, CHAT, DGKH, DGKQ, } \\
\text { DGKZ, ETNK1, GNPAT, GPAM, } \\
\text { LYPLA1, PEMT, PPAP } 2 A, T A Z\end{array}$ \\
\hline $\begin{array}{l}\text { Fanconi anemia pathway - } \\
\text { Homo sapiens }\end{array}$ & 0.03646938 & 8 & 1.438072 & $\begin{array}{l}B L M, F A N C B, F A N C D 2, F A N C E, \\
F A N C F, R P A 2, S T R A 13, \text { WDR } 48\end{array}$ \\
\hline $\begin{array}{l}\text { Alcoholism - } \\
\text { Homo sapiens }\end{array}$ & 0.03755879 & 20 & 1.425288 & $\begin{array}{l}\text { BDNF, CAMK4, CREB3L2, GNAS, GNG13, } \\
\text { GRIN2A, GRIN2C, GRIN2D, H2AFV, } \\
\text { H2BFM, HIST1H3F, HIST1H4D, } \\
\text { HIST2H2AB, HIST2H2BF, HIST2H3D, } \\
\text { HIST3H3, MAOA, MAPK1, NTRK2,TH }\end{array}$ \\
\hline $\begin{array}{l}\text { PI3K-Akt signaling pathway - } \\
\text { Homo sapiens }\end{array}$ & 0.04341327 & 34 & 1.362377 & $\begin{array}{l}\text { BCL2L11, CDKN1A, CDKN1B, } \\
\text { CHAD, COL6A1, CREB3L2, EGFR, EPOR, } \\
\text { FASLG, FGF1, FLT1, GNG13, HSP90AA1, } \\
\text { HSP90B1, INSR, ITGAV,ITGB4, JAK2, } \\
\text { KITLG, LAMA5, LAMC3, MAPK1, } \\
\text { PIK3R3, PPP2R1A, PPP2R2B, PPP2R3A, } \\
\text { PPP2R5E, PRKCZ, PTEN, PTK2, } \\
\text { SGK1, THEM4, TLR2, YWHAZ }\end{array}$ \\
\hline
\end{tabular}


Table IV. Continued.

\begin{tabular}{|c|c|c|c|c|}
\hline $\begin{array}{l}\text { KEGG } \\
\text { pathways }\end{array}$ & $\begin{array}{l}\text { Fisher } \\
\text { (n) }\end{array}$ & $\begin{array}{l}\text { Gene } \\
\text { P-value }\end{array}$ & $\begin{array}{l}\text { Enrichment } \\
\text { score }\end{array}$ & Genes \\
\hline $\begin{array}{l}\text { HIF-1 signaling pathway - } \\
\text { Homo sapiens }\end{array}$ & 0.04345306 & 13 & 1.36198 & $\begin{array}{l}\text { ALDOA, CAMK2D, CDKN1A, } \\
C D K N 1 B, E G F R, F L T 1, I F N G R 1, I N S R, \\
\text { MAPK1, PGK1, PIK3R3, SLC2A1,TF }\end{array}$ \\
\hline $\begin{array}{l}\text { DNA replication - } \\
\text { Homo sapiens }\end{array}$ & 0.04358268 & 6 & 1.360686 & $\begin{array}{l}\text { MCM2, PCNA, POLA2, RFC2, } \\
\text { RNASEH } 2 C, \text { RPA2 }\end{array}$ \\
\hline $\begin{array}{l}\text { Focal adhesion - } \\
\text { Homo sapiens }\end{array}$ & 0.04412979 & 22 & 1.355268 & $\begin{array}{l}\text { BCAR1, CHAD, COL6A1, CRK, CRKL, } \\
\text { EGFR, ELK1, FLNC, FLT1, ITGAV, } \\
\text { ITGB4, LAMA5, LAMC3, MAPK1, } \\
\text { MYL12A, MYLK2, MYLK3, PIK3R3, } \\
\text { PPP1R12B, PTEN, PTK2, VCL }\end{array}$ \\
\hline
\end{tabular}

Fisher P-value, the enrichment P-value of the Pathway ID using Fisher's exact test; Enrichment score: the enrichment score value of the pathway ID, which equals $[-\log 10(\mathrm{P}$-value) $]$.
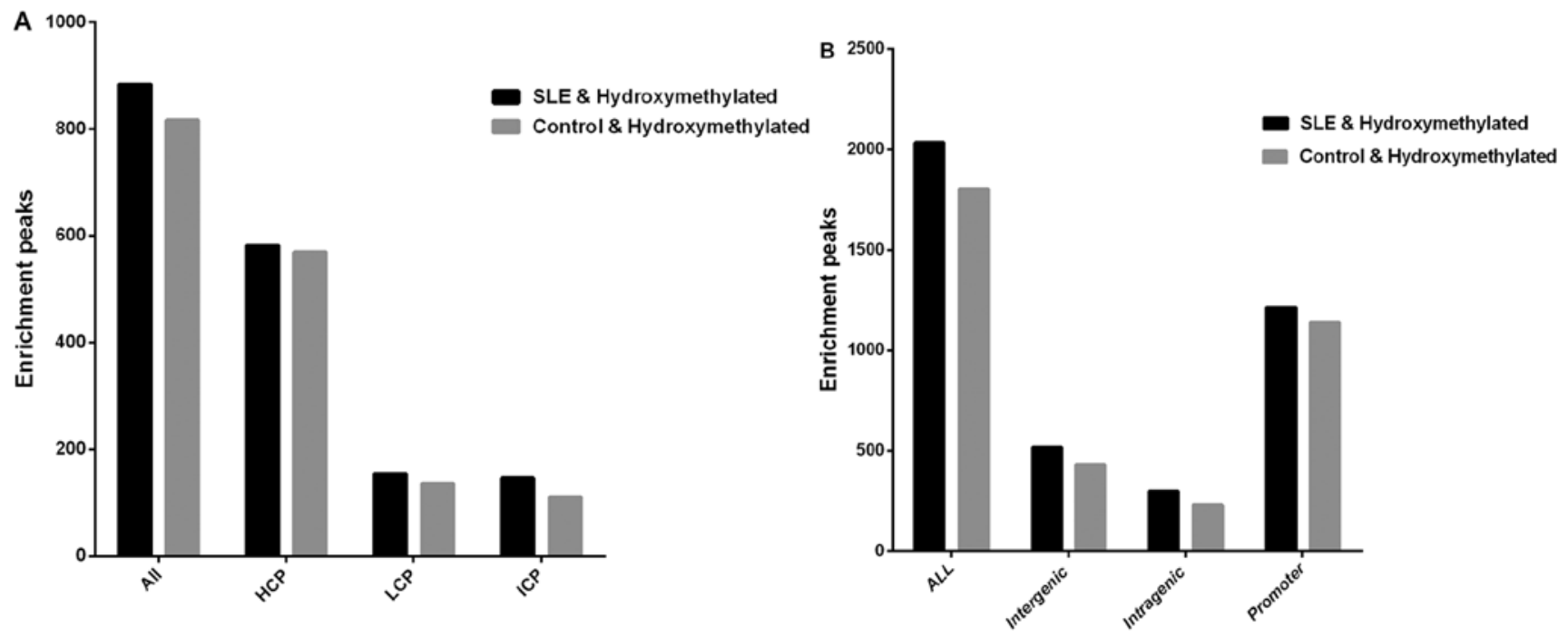

Figure 5. Different DNA hydroxymethylation level in the blood of SLE patients compared with the normal controls. (A) Different DNA hydroxymethylation levels in gene promoter $(-800$ to $+200 \mathrm{bp})$, in the whole blood cells of SLE patients compared with the normal controls. (B) Different DNA hydroxymethylation levels in CpG Islands, in the whole blood cells of SLE patients compared with the normal controls.

hyper-hydroxymethylated within the $\mathrm{CpG}$ islands in the SLE patients compared with the normal controls (clockwise from chromosome 1 to the $\mathrm{X}$ and $\mathrm{Y}$ sex chromosomes). The percentage of genes hyper-hydroxymethylated on chromosome 29 was $9 \%$ (Fig. 6B).

The 5 -hmC modifications of 15 selected genes are shown in Table V. The selected genes showed the greatest differences. Of these genes, we selected three prime repair exonuclease 1 (TREX1), cyclin-dependent kinase inhibitor 1A (p21, Cip1; CDKN1A), and cyclin-dependent kinase inhibitor 1B (p27, Kip1; CDKN1B) for verification. The microarray data were consistent with the RT-qPCR results (Table VI) showing that TREX1, CDKNIA, and CDKN1B exhibited significantly increased levels of 5-hmC. The three genes showed the largest differences in 5-hmC levels and may therefore be associated with SLE.

\section{Discussion}

The 5-hmC modification has been identified in mammalian DNA (6), but its broader role in epigenetics remains to be resolved. Early evidence suggests a few putative mechanisms that have potentially important implications (18): i) Conversion of methylcytosine $(5-\mathrm{mC})$ to $5-\mathrm{hmC}$ may displace methyl-binding proteins (MBPs). MeCP2, for instance, does not bind to 5 -hmC. ii) 5 -hmC may induce demethylation by interfering with the methylation maintenance function of DNMT1 during cell division. iii) 5-hmC may have its own specific binding proteins that alter the chromatin structure or DNA methylation patterns.

5-hmC was previously observed; however, little is known regarding its subtle interrelationship with other epigenetic modifications and potential functional significance in human 

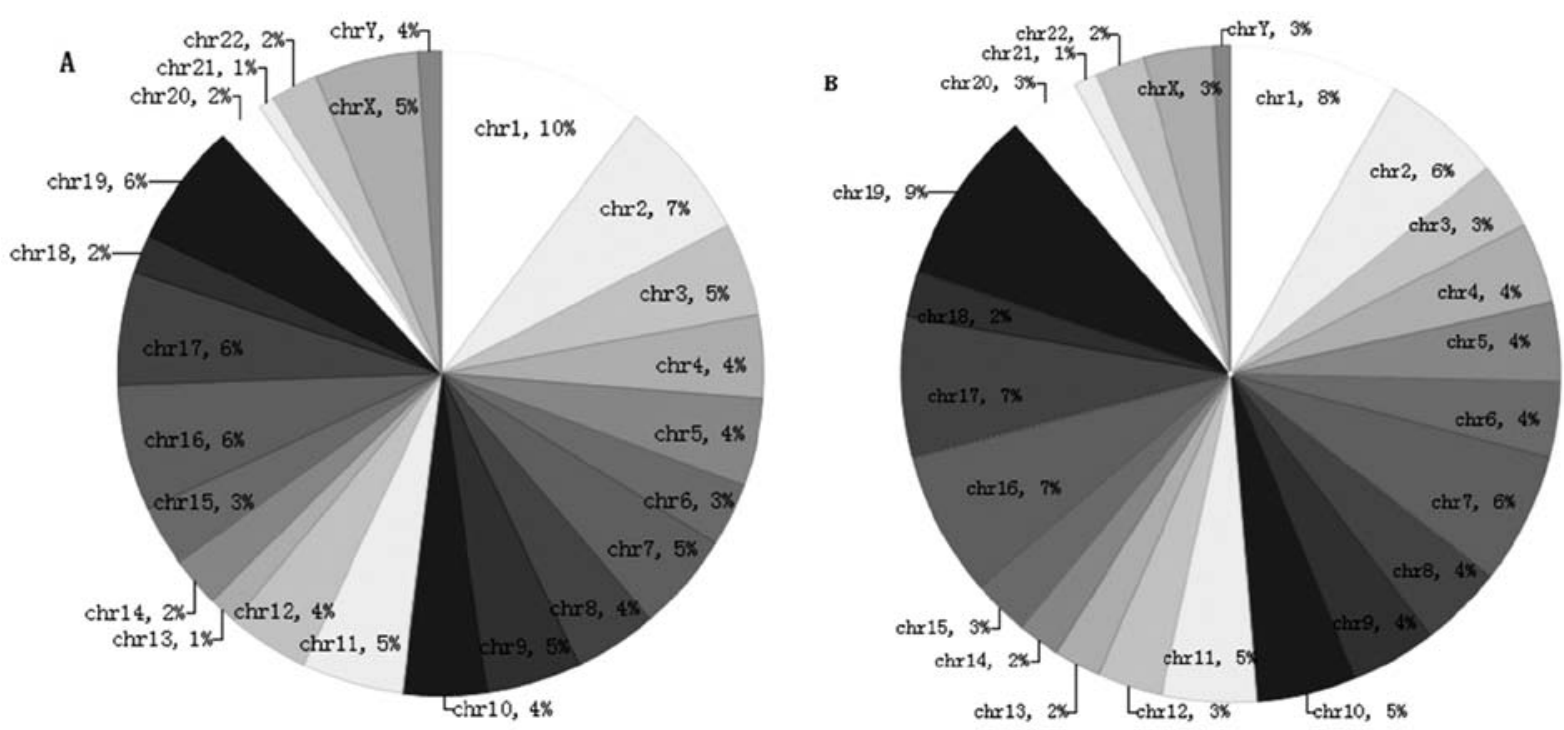

Figure 6. Pie charts showing the chromosomal location of the upregulated genes in SLE patients that compared to normal controls. (A) Pie charts showing the chromosomal location of the 884 genes that were upregulated in the gene promoter (clockwise from chromosome 1 to $\mathrm{X}$ and $\mathrm{Y}$ sex chromosomes). The percentage of genes upregulated on chromosome 1 is $10 \%$. (B) Pie charts showing the chromosomal location of the 2,034 genes that were upregulated in CpG islands (clockwise from chromosome 1 to $\mathrm{X}$ and $\mathrm{Y}$ sex chromosomes). The percentage of genes upregulated on the chromosome 19 is $9 \%$.

Table V. The 15 selected genes with hydroxymethylation alterations between SLE and normal controls, identified by hmeDIP-seq.

\begin{tabular}{lllll}
\hline Peak ID & Gene name & \multicolumn{1}{c}{ Peak region } & Peak score & Peak M-value \\
\hline 4636 & RTN1 & Chr14: $59263472-59264121$ & 4.71 & 1.26471321387763 \\
3845 & SIOOA7L2 & Chr1: 151678931-151679801 & 4.55 & 0.967562504015608 \\
5554 & ZNRF4 & Chr19: $5406466-5407310$ & 4.48 & 1.10626932760703 \\
5087 & CPNE7 & Chr16: $88168557-88169204$ & 4.37 & 1.37675784921923 \\
7131 & FZD3 & Chr8: $28406910-28407744$ & 4.35 & 1.00487584265558 \\
4370 & LAYN & Chr11: $110916352-110917416$ & 4.32 & 0.86128687613001 \\
6211 & LZTR1 & Chr22: $19665877-19666606$ & 4.32 & 1.21336961342519 \\
3824 & PRMT6 & Chr1: $107400534-107401083$ & 4.23 & 0.934008953032345 \\
7529 & VMA21 & ChrX: $150315981-150316530$ & 4.13 & 1.16048247400229 \\
6560 & FREM3 & Chr4: $144840477-144841631$ & 4.09 & 1.18891146363541 \\
3911 & HIST3H3 & Chr1: 226679229-226679963 & 4.07 & 1.33700123117401 \\
6204 & GNB1L & Chr22: $18221904-18222633$ & 2.7 & 0.77963334561276 \\
6355 & TREX1 & Chr3: $48482232-48484048$ & 2.66 & 0.450419940777759 \\
6777 & CDKN1A & Chr6: $36754464-36763087$ & 2.03 & 1.58157470937086 \\
679 & CDKN1B & Chr12: $12761568-12766572$ & 0.6574848262603 \\
\hline
\end{tabular}

Peak score, the average $-\log 10$ (P-value) from probes within the peak. The scores reflect the probability of positive enrichment $($ cut off $=2)$. Peak M-value, the median log2-ratio from probes within the peak region. The score reflects the hydroxymethylation level of the region.

disease. In this study, we selected 5-hmC as the target, performed an investigation using hMeDIP-chip, and investigated the hypothesis that $5-\mathrm{hmC}$ is associated with the pathogenesis of SLE. We mainly analyzed the levels of 5-hmC in SLE patients and normal controls. The identified candidate genes with significant differences in 5-hmC levels are shown in Table V. This list includes genes associated with immunity, cell signal transduction, protein transcription and synthesis, ion channels and transporters, and the extracellular matrix.

Of the identified candidate genes, we found that TREXI was hyper-hydroxymethylated in the SLE patients compared with the normal controls. Three prime repair exonuclease 1 (TREX1) is located on chromosome $3 \mathrm{p} 21.31$ and is also known as $C R V, A G S 1, D R N 3$ or HERNS. This gene encodes a nuclear protein with $3^{\prime}$ exonuclease activity, which may play a role in DNA repair and serve a proofreading function for DNA polymerase. Mutations in this gene result in AicardiGoutieres syndrome, chilblain lupus, Cree encephalitis, and other diseases of the immune system. Alternative splicing of this gene results in multiple transcript variants.

TREX1 plays a key role in the HIV-1 infection process (19). This protein degrades excess HIV-1 DNA, thereby preventing 
Table VI. RT-qPCR verification results.

\begin{tabular}{|c|c|c|c|c|c|c|c|}
\hline \multirow[b]{2}{*}{ Sample } & \multicolumn{3}{|c|}{ Input-IP } & \multicolumn{3}{|c|}{ Input-neg } & \multirow[b]{2}{*}{ IP/neg } \\
\hline & Input $(\mathrm{Ct})$ & $\mathrm{IP}(\mathrm{Ct})$ & $\%$ & Input $(\mathrm{Ct})$ & $\operatorname{Neg}(\mathrm{Ct})$ & $\%$ & \\
\hline \multicolumn{8}{|l|}{ TREXI } \\
\hline SLE & 26.628 & 29.827 & 2.178 & 26.628 & NA & NA & - \\
\hline Normal controls & 25.648 & 37.884 & 0.004 & 25.648 & NA & NA & - \\
\hline \multicolumn{8}{|l|}{$C D K N 1 A$} \\
\hline SLE & 23.375 & 28.664 & 0.512 & 23.375 & NA & NA & - \\
\hline Normal controls & 22.38 & NA & NA & 25.648 & 22.38 & NA & - \\
\hline \multicolumn{8}{|l|}{$C D K N 1 B$} \\
\hline SLE & 26.474 & 33.43 & 0.161 & 26.474 & NA & NA & - \\
\hline Normal controls & 27.284 & 33.512 & 0.267 & 27.284 & NA & NA & - \\
\hline
\end{tabular}

$\%$ Input $=2\left(\mathrm{Ct}^{\mathrm{tnput}}-\mathrm{Ct}^{\mathrm{ChIP}}\right) \times \mathrm{Fd} \times 100 \%$. Fd refers to input dilution factor: For example, when $100 \mu 1$ sonicated sample was used for hMeDIP and $20 \mu 1$ sonicated sample was used as Input, $\mathrm{Fd}=1 / 5$.

recognition by innate immunity receptors and the type I interferon response. Rare mutations in the TREXI gene, the major mammalian 3'-5' exonuclease, have been reported in sporadic SLE cases $(20,21)$. Some of these mutations have also been identified in a rare pediatric neurological condition featuring an inflammatory encephalopathy known as Aicardi-Goutieres syndrome (AGS) (22). The mutations have also been identified in patients with several different human diseases (23), such as Aicardi-Goutieres syndrome 1, and account for all the mutations in retinal vasculopathy with cerebral leukodystrophy. These mutations include null alleles, frameshift mutations and non-synonymous changes in the catalytic domains and the C-terminal region. In AGS, most TREXI mutations are autosomal recessive and reduce exonuclease activity of the enzyme, in particular a transition of arginine to histidine at position 114 (R114H). Pulliero et al described mutations of the TREX1 gene in Aicardi-Goutières syndrome 1 that increase the ability of T-lymphocytes to inhibit the growth of neoplastic neuronal cells and related angiogenesis (24).

In SLE, most of the mutations reported thus far are heterozygous and are located outside of the catalytic domain in the C-terminal region. The functional significance of these mutations is unknown. To examine the frequency of mutations in the TREXI gene and their relationship with SLE, Namjou et al (25) genotyped 40 SNPs in the TREXI genomic region, including previously reported rare SNPs and more common tag SNPs that capture most of the variation in this region. Those authors reported results indicating that TREXI is involved in the lupus pathogenesis and is most likely essential for the prevention of autoimmunity. Gene Ontology (GO) term analysis shows that TREXI is mainly associated with the cell process, cellular nitrogen compound metabolic process, cell response to stress, intracellular component, intracellular, binding, and protein binding.

We also observed that $C D K N 1 A$ was significantly hyper-hydroxymethylated and $C D K N 1 B$ was significantly hypo-hydroxymethylated in the SLE patients compared with the normal controls. The cyclin-dependent kinase inhibitor 1A (p21, Cip1; CDKN1A) gene is located on chromosome 6p21.2 and is also known as P21,CIP1,SDI1,WAF1, CAP20, $C D K N 1, M D A-6$ or $p 21 C I P 1$. This gene encodes a potent cyclin-dependent kinase inhibitor. The encoded protein binds to and inhibits the activity of the cyclin-CDK2 or -CDK4 complexes and thus functions as a regulator of G1 cell cycle progression. The expression of this gene is closely regulated by the tumor-suppressor protein p53 and mediates the p53-dependent G1 cell cycle arrest in response to a variety of stress stimuli. This protein can interact with proliferating cell nuclear antigen (PCNA), a DNA polymerase accessory factor, and plays a regulatory role in DNA replication and DNA damage repair. This protein was reported to be specifically cleaved by CASP3-like caspases, which leads to marked activation of CDK2 and may be instrumental in the execution of apoptosis following caspase activation. Multiple alternatively spliced variants have been identified for this gene.

The CDKNIA gene that encodes a cell cycle inhibitor, p21 (WAF1/CIP1), is located in a region associated with SLE susceptibility. Decreased cell levels of p21 are associated with SLE $(26,27)$. Single-nucleotide polymorphisms (SNPs) within the promoter and the first intron of CDKNIA are associated with SLE susceptibility. The minor allele A at nucleotide 899 of CDKN1A is associated with increased susceptibility to SLE and lupus nephritis and decreased cell levels of p21.

The cyclin-dependent kinase inhibitor 1B (p27, Kip1; $C D K N 1 B$ ) encodes a cyclin-dependent kinase inhibitor, which shares a limited similarity with the CDK inhibitor $C D K N 1 A / p 21$. The encoded protein binds to and prevents the activation of the cyclin $E$ - $C D K 2$ or cyclin $D$-CDK4 complexes and thus controls G1 cell cycle progression. The degradation of this protein, which is triggered by its CDK-dependent phosphorylation and subsequent ubiquitination by SCF complexes, is required for the cellular transition from quiescence to the proliferative state.

CDKN1B (28) may lead to defects in apoptosis or autophagy and thus increase exposure of nuclear autoantigens to the immune system, and its potential role in autoimmunity is 
supported by numerous functional studies. $C D K N 1 B$ encodes p27Kip1, a cyclin-dependent kinase (CDK) inhibitor, which plays a critical role in the inhibition of cell-cycle progression, especially in T lymphocytes. p27Kip1 is essential for the induction of tolerance, a process believed to be at the center of autoimmune diseases such as SLE, and upregulation of p27Kip1 was found to correlate with the induction of anergy in vitro and tolerance in vivo. p27Kip1 is also involved in dendritic cell apoptosis, and the potential roles of the identified susceptibility genes in SLE etiology are noted. GO term analysis indicates that $C D K N 1 A$ and $C D K N 1 B$ are strongly associated with the cell process, intracellular component, intracellular, binding, and protein binding.

In this study, we systematically evaluated the genomewide levels of 5-hmC in the DNA of SLE patients and gained insight into the connections between key genes and 5-hmC in the context of SLE. Our results indicate that $5-\mathrm{hmC}$ is involved in the disease state and these novel candidate genes may become potential biomarkers or future therapeutic targets. Future investigations are needed to clarify the roles of the identified hydroxymethylated candidate genes in the pathogenesis of SLE.

\section{Acknowledgements}

The authors are deeply grateful to all the volunteers. This study was supported by the Guangxi Natural Science Foundation (no. 2012GXNSFDA053017) and by the Guangxi Key Laboratory of Metabolic Diseases Research (no. 12-071-32).

\section{References}

1. Woodman I: Connective tissue diseases: The MECP2/IRAK1 locus modulates SLE risk via epigenetics. Nat Rev Rheumatol 9: 197, 2013.

2. Baizabal-Carvallo JF, Alonso-Juarez $M$ and Koslowski M: Chorea in systemic lupus erythematosus. J Clin Rheumatol 17: 69-72, 2011.

3. Ponticelli C, Glassock RJ and Moroni G: Induction and maintenance therapy in proliferative lupus nephritis. J Nephrol 23: $9-16,2010$.

4. Thabet Y, Cañas F, Ghedira I, Youinou P, Mageed RA and Renaudineau Y: Altered patterns of epigenetic changes in systemic lupus erythematosus and auto-antibody production: is there a link? J Autoimmun 39: 154-160, 2012.

5. Sui W, Hou X, Che W, Yang M and Dai Y: The applied basic research of systemic lupus erythematosus based on the biological omics. Genes Immun 14: 133-146, 2013.

6. Tahiliani M, Koh KP, Shen Y, et al: Conversion of 5-methylcytosine to 5-hydroxymethylcytosine in mammalian DNA by MLL partner TET1. Science 324: 930-935, 2009.

7. Huang Y, Pastor WA, Shen Y, Tahiliani M, Liu DR and Rao A: The behaviour of 5-hydroxymethylcytosine in bisulfite sequencing. PLoS One 5: e8888, 2010.

8. Ito S, D'Alessio AC, Taranova OV, Hong K, Sowers LC and Zhang Y: Role of Tet proteins in $5 \mathrm{mC}$ to $5 \mathrm{hmC}$ conversion, ES-cell self-renewal and inner cell mass specification. Nature 466: 1129-1133, 2010.
9. Yamaguchi S, Hong K, Liu R, et al: Dynamics of 5-methylcytosine and 5-hydroxymethylcytosine during germ cell reprogramming. Cell Res 23: 329-339, 2013.

10. Jin SG, Kadam S and Pfeifer GP: Examination of the specificity of DNA methylation profiling techniques towards 5-methylcytosine and 5-hydroxymethylcytosine. Nucleic Acids Res 38: e125, 2010.

11. Wu SC and Zhang Y: Active DNA demethylation: many roads lead to Rome. Nat Rev Mol Cell Biol 11: 607-620, 2010.

12. Williams K, Christensen J and Helin K: DNA methylation: TET proteins-guardians of CpG islands? EMBO Rep 13: 28-35, 2011.

13. Song CX, Yi C and He C: Mapping recently identified nucleotide variants in the genome and transcriptome. Nat Biotechnol 30: 1107-1116, 2012 .

14. Stroud H, Feng S, Morey Kinney S, Pradhan S and Jacobsen SE: 5-Hydroxymethylcytosine is associated with enhancers and gene bodies in human embryonic stem cells. Genome Biol 12: R54, 2011.

15. Xu Y, Wu F, Tan L, et al: Genome-wide regulation of 5hmC, $5 \mathrm{mC}$, and gene expression by Tet1 hydroxylase in mouse embryonic stem cells. Mol Cell 42: 451-464, 2011.

16. Gao Y, Chen J, Li K, et al: Replacement of Oct4 by Tet1 during iPSC induction reveals an important role of DNA methylation and hydroxymethylation in reprogramming. Cell Stem Cell 12: 453-469, 2013.

17. Thomson JP, Lempiäinen H, Hackett JA, et al: Non-genotoxic carcinogen exposure induces defined changes in the 5-hydroxymethylome. Genome Biol 13: R93, 2012.

18. Guo JU, Su Y, Zhong C, Ming GL and Song H: Hydroxylation of 5-methylcytosine by TET1 promotes active DNA demethylation in the adult brain. Cell 145: 423-434, 2011.

19. Sironi M, Biasin M, Forni D, et al: Genetic variability at the TREX1 locus is not associated with natural resistance to HIV-1 infection. AIDS 26: 1443-1445, 2012.

20. Hur JW, Sung YK, Shin HD, Cheong HS and Bae SC: TREX1 polymorphisms associated with autoantibodies in patients with systemic lupus erythematosus. Rheumatol Int 28: 783-789, 2008.

21. Lee-Kirsch MA, Gong M, Chowdhury D, et al: Mutations in the gene encoding the 3'-5' DNA exonuclease TREX1 are associated with systemic lupus erythematosus. Nat Genet 39: 1065-1067, 2007.

22. O'Driscoll M: TREX1 DNA exonuclease deficiency, accumulation of single stranded DNA and complex human genetic disorders. DNA Repair 7: 997-1003, 2008.

23. Kavanagh D, Spitzer D, Kothari PH, et al: New roles for the major human 3'-5' exonuclease TREX1 in human disease. Cell Cycle 7: 1718-1725, 2008.

24. Pulliero A, Marengo B, Domenicotti C, et al: Inhibition of neuroblastoma cell growth by TREX1-mutated human lymphocytes. Oncol Rep 27: 1689-1694, 2012.

25. Namjou B, Kothari PH, Kelly JA, et al: Evaluation of the TREX1 gene in a large multi-ancestral lupus cohort. Genes Immun 12: 270-279, 2011.

26. Kim K, Sung YK, Kang CP, Choi CB, Kang C and Bae SC: A regulatory SNP at position -899 in CDKN1A is associated with systemic lupus erythematosus and lupus nephritis. Genes Immun 10: 482-486, 2009.

27. Miyagawa H, Yamai M, Sakaguchi D, et al: Association of polymorphisms in complement component $\mathrm{C} 3$ gene with susceptibility to systemic lupus erythematosus. Rheumatology 47 : 158-164, 2008

28. Yang W, Tang H, Zhang Y, et al: Meta-analysis followed by replication identifies loci in or near CDKN1B, TET3, CD80, DRAM1, and ARID5B as associated with systemic lupus erythematosus in Asians. Am J Hum Genet 92: 41-51, 2013. 